\title{
Islands in the City
}


This page intentionally left blank 


\title{
Islands in the City
}

West Indian Migration to New York

\author{
EDITED BY \\ Nancy Foner
}

UNIVERSITY OF CALIFORNIA PRESS

Berkeley Los Angeles London 


\author{
University of California Press \\ Berkeley and Los Angeles, California \\ University of California Press, Ltd. \\ London, England \\ (C) 200 I by \\ The Regents of the University of California
}

Islands in the city : West Indian migration to New York / edited by Nancy Foner.

p. cm.

Based on a conference entitled West Indian migration to New York : historical, contemporary, and transnational perspectives, which was held at the Research Institute for the Study of Man in April I999.

Includes bibliographical references and index.

ISBN 0-520-22573-2 (cloth : alk. paper) - ISBN 0-520-22850-2 (pbk. : alk. paper)

I. West Indian Americans - New York (State)-New York-Social conditions - Congresses. 2. West Indian Americans - New York (State) - New York - Race identity - Congresses. 3. BlacksNew York (State) - New York - Social conditions - Congresses. 4. Blacks - Race identity - New York (State) - New York - Congresses. 5. Immigrants - New York (State)-New York - Social conditions - Congresses. 6. New York (N.Y.) - Social conditions-Congresses. 7. New York (N.Y.) - Race relations - Congresses. 8. New York (N.Y.) - Emigration and immigrationCongresses. 9. West Indies - Emigration and immigration - Congresses. I. Foner, Nancy, I945FI28.9.W54 I85 200I $305.896^{\prime} 97290747-\mathrm{dc} 2 \mathrm{I}$

$$
\text { 00-0467II }
$$

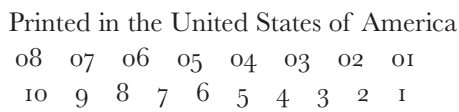

The paper used in this publication meets the minimum requirements of ANSI/NISO Z39.48-I984 (R 1997) (Permanence of Paper). 